\title{
Symmetrically and Unsymmetrically Substituted Bis(pyrazole)-palladium(II) and Nickel(II) Halides as Pre-catalysts for Ethylene dimerization and Friedel-Crafts Alkylation of Toluene and Benzene
}

\author{
Lerato P. Moeti and James Darkwa* \\ Department of Chemistry, University of Johannesburg, Auckland Park Kingsway Campus, P.O Box 524, Auckland Park, 2006, South Africa.
}

Received 15 October 2015, revised 12 June 2016, accepted 13 October 2016.

\begin{abstract}
Bis(pyrazole)-palladium(II) and nickel(II) halide complexes, $\left[(\mathrm{pz})_{2} \mathrm{PdCl}_{2}\right](\mathbf{1}),\left[\left(3,5-\mathrm{Me}_{2} \mathrm{pz}_{2} \mathrm{PdCl}_{2}\right](2),\left[\left(3,5-{ }^{t} \mathrm{Bu}_{2} \mathrm{pz}_{2} \mathbf{P d C l}_{2}\right](3)\right.\right.$, $\left[\left(3,5-\mathrm{Ph}_{2} \mathrm{pz}_{2} \mathrm{PdCl}_{2}\right](4),\left[\left(3-\mathrm{CF}_{3}, 5-\mathrm{Phpz}_{2} \mathrm{PdCl}_{2}\right](5),\left[(\mathrm{pz})_{4} \mathrm{NiBr}_{2}\right](6),\left[\left(3,5-\mathrm{Me}_{2} \mathrm{pz}_{2} \mathrm{NiBr}_{2}\right](7),\left[\left(3,5-{ }_{-} \mathrm{Bu}_{2} \mathrm{pz}_{2} \mathrm{NiBr}_{2}\right](8)\right.\right.\right.\right.$, $\left[\left(3,5-\mathrm{Ph}_{2} \mathrm{pz}\right)_{2} \mathrm{NiBr}_{2}\right](9)$ and $\left[\left(3-\mathrm{CF}_{3}, 5-\mathrm{Phpz}_{2} \mathrm{NiBr}_{2}\right](10)\right.$, were investigated as catalysts for ethylene oligomerization using four alkylaluminium compounds as co-catalysts in toluene, benzene and chlorobenzene. The palladium complexes with ethylaluminium dichloride $\left(\mathrm{EtAlCl}_{2}\right)$ in toluene selectively produced ethyl- and butyl- toluenes via a Friedel-Crafts alkylation of toluene from the ethylene and butenes formed from the dimerization of ethylene. On the other hand, the nickel complexes produced a mixture of butenes and their Friedel-Crafts toluene alkylation products, but very little ethyltoluene. Changing the solvent to benzene produced similar alkyl-aromatics but in chlorobenzene the reaction produced butenes and a yellow oil, with a molecular weight between 501 to $509 \mathrm{~g} \mathrm{~mol}^{-1}$; representing $\mathrm{C}_{18}-\mathrm{C}_{20}$ carbon-containing compounds. Similarly changing the co-catalyst to methylaluminoxane (MAO), modified methylaluminoxane (MMAO), diethylaluminium chloride ( $\left.\mathrm{Et}_{2} \mathrm{AlCl}\right)$ and ethylaluminiumsesquichloride $\left(\mathrm{Et}_{3} \mathrm{Al}_{2} \mathrm{Cl}_{3}\right)$ also selectively produced butenes and little or no alkylaromatics.
\end{abstract}

KEYWORDS

Substituted pyrazoles, palladium(II) and nickel(II) halides, ethylene dimerization, Friedel-Crafts alkylation.

\section{Introduction}

The last two decades have witnessed increased activity in developing single-site homogeneous ethylene oligomerization and polymerization catalysts in attempts to address some of the problem associated with heterogeneous catalysts for the polymerization of ethylene and other linear $\alpha$-olefins. ${ }^{1}$ These unique compounds have the potential to control product distribution and microstructure while displaying high catalytic activity through the modification of both the steric and electronic properties in a manner that is impossible with heterogeneous catalysts. $^{2}$ Interest in late transition metals olefin oligomerization and polymerization catalysts has particularly grown recently, especially nickel and palladium catalysts that have nitrogendonor ligands. These are of particular interest due to their ease of synthesis and stability to air and moisture..$^{3-5}$ The remarkable ability of these nitrogen-donor ligands nickel and palladium catalysts to produce olefin oligomers has resulted in the development of pyrazolyl palladium and nickel complexes as the new nitrogen-donor late transition metals ethylene transformation catalysts. ${ }^{6,7}$ In $2002 \mathrm{Li}$ et al. $^{6}$ synthesized the first examples bis-pyrazole palladium complexes as ethylene polymerization catalysts. Nelana et al. ${ }^{7}$ later reported nickel analogues of the palladium compounds as highly active ethylene polymerization catalysts that produced linear high-density polyethylene (LHDPE) when the co-catalyst is methylaluminoxane (MAO).

Several groups have since developed other nitrogen-donor nickel ethylene oligomerization and polymerization catalysts. ${ }^{8}$ Much of the catalyst development has been on $\mathrm{P}^{\wedge} \mathrm{N}$ and $\mathrm{N}^{\wedge} \mathrm{N}$

* To whom correspondence should be addressed. E-mail: jdarkwa @uj.ac.za donor nickel ethylene oligomerization reactions which produce mainly dimerization and trimerization products. But in these dimerization and trimerization reactions, the role of alkylaluminium co-catalysts has only recently been brought into focus following reports by Dyer et al., ${ }^{9}$ Gao et al., ${ }^{10}$ Ojwach et al. ${ }^{11}$ and Budhai et al. ${ }^{12}$ These reports on ethylene oligomerization and post-oligomerization Friedel-Crafts alkylation of toluene show the importance of $\mathrm{EtAlCl}_{2}$ as a co-catalyst and the solvent in which the ethylene oligomerization reactions are run. Dyer et al.,${ }^{9}$ Gao et al. ${ }^{10}$ Ojwach et al..$^{11}$ and others ${ }^{12}$ have all reported the formation of alkyltoluenes as secondary products. However, only selected nickel catalysts from the Dyer ${ }^{9}$ and $\mathrm{Gao}^{10}$ systems gave Friedel-Crafts alkylation secondary products. But what is unique about the nickel catalysts reported by Ojwach et al. ${ }^{11}$ and Budhai $^{12 b}$ is that they all catalyze ethylene oligomerization followed by the formation of large amounts of alkyltoluenes via the Friedel-Crafts alkylation of toluene with the ethylene oligomers formed in the reaction. This points to the possible role the pyrazolyl ligands in the nickel catalysts play in promoting the alkylation reactions; although the exact nature of how this promotes the Friedel-Crafts alkylation remains a subject of much speculation. Nonetheless, a catalyst system that can simultaneously produce ethylene oligomers and alkyltoluenes is highly desirable as alkyltoluenes can be starting materials for detergents and surfactants.

In this project we sought to investigate the effect of varying alkylaluminium co-catalysts on ethylene reactions when bis(pyrazole)palladium and nickel complexes were used as pre-catalysts. 


\section{Results and Discussions}

\subsection{Synthesis of Bis(pyrazole) Palladium and Nickel Complexes}

Bis(substituted-pyrazole)palladium(II) and nickel(II) halides were prepared according to literature procedures from $\left[\mathrm{PdCl}_{2}(\mathrm{NCMe})_{2}\right]^{6}$ and $\left[\mathrm{NiBr}_{2}(\mathrm{DME})\right]_{;}^{7}$ except for compounds 5 and 10, which are new and were prepared from (3-trifluoromethyl-5-phenylpyrazole) (L5) and $\left[\mathrm{PdCl}_{2}(\mathrm{NCMe})_{2}\right]$ and $\left[\mathrm{NiBr}_{2}(\mathrm{DME})\right]$, respectively (Scheme 1).

Comparison of the ${ }^{1} \mathrm{H},{ }^{13} \mathrm{C}\left\{{ }^{1} \mathrm{H}\right\}$ NMR and IR spectral data of compounds 1-4 and 6-9 are similar to those reported in the literature. ${ }^{1,7}$ Compounds L5, $\mathbf{5}$ and $\mathbf{1 0}$ were characterized by a combination of ${ }^{1} \mathrm{H},{ }^{19} \mathrm{~F}\left\{{ }^{1} \mathrm{H}\right\},{ }^{13} \mathrm{C}\left\{{ }^{1} \mathrm{H}\right\}$ NMR and IR spectroscopy, by elemental analysis and HR-MS as shown in the supplementary materials (Figs. S1-S4). ${ }^{19} \mathrm{~F}\left\{{ }^{1} \mathrm{H}\right\}$ NMR spectra of L5 and $\mathbf{5}$ showed singlets at $-62.22 \mathrm{ppm}$ and $-60.41 \mathrm{ppm}$, respectively, representing the three fluorine atoms in the triflouromethyl substituents on the pyrazole ring in L5 and $\mathbf{5}$ (Fig. S3). No coupling of carbon to fluorine in the ${ }^{19} \mathrm{~F}\left\{{ }^{1} \mathrm{H}\right\}$ NMR spectra was observed; this is due to the low natural abundance of ${ }^{13} \mathrm{C}$. However, the ${ }^{13} \mathrm{C}\left\{{ }^{1} \mathrm{H}\right\}$ NMR spectra of $\mathbf{L} \mathbf{5}$ and $\mathbf{5}$ showed coupling of the three fluorine atoms to the carbon atoms with the triflouro- methyl substituents on the pyrazole resulting in quartets (Fig. S2). The peak for the carbon in position 4 of the pyrazole ring showed a slight downfield shift from $100.9 \mathrm{ppm}$ in L5 to 101.5 ppm in 5, while the quaternary carbons were very low intensity upfield peaks at $142.5 \mathrm{ppm}$ and $144.6 \mathrm{ppm}$ in the ligand and the palladium complex, respectively.

\subsection{Oligomerization of Ethylene and Subsequent in situ Friedel-Crafts Alkylation Reactions}

\subsubsection{Screening of Complexes 1-10 and Determination of Optimum} Co-catalyst Concentrations

Preliminary investigation of the suitability of these pyrazole palladium and nickel complexes as catalysts for ethylene oligomerization was conducted with $\mathrm{EtAlCl}_{2}$ as a co-catalyst. All the palladium and nickel complexes were found to be active for the dimerization of ethylene and the subsequent Friedel-Crafts alkylation of toluene by ethylene and butenes, but the palladium complexes formed less butenes and more ethyltoluenes (Table 1). Complexes 5 and $\mathbf{1 0}$ had the highest catalytic activities among the complexes tested which can be attributed to the $\mathrm{CF}_{3}$ group on the pyrazole. In fact, the $\mathrm{CF}_{3}$ functional group has been reported to increase catalytic activity of some metal complexes. ${ }^{13}$

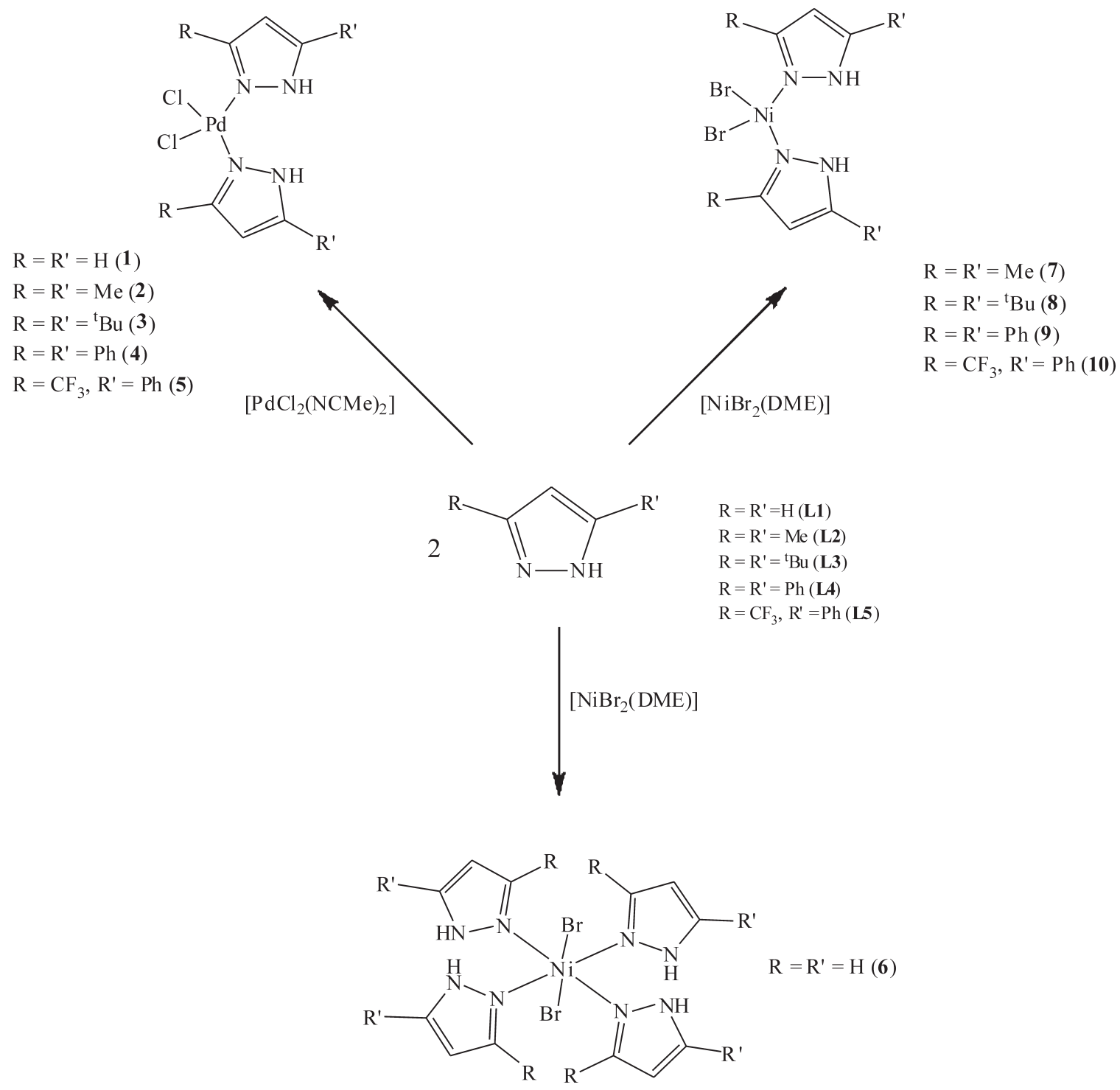

Scheme 1

General reaction scheme for the preparation of palladium(II) and nickel(II) halide pre-catalysts. 
Table 1 Screening of pre-catalysts 1-10 for ethylene oligomerization reactions using ethylaluminium dichloride as co-catalyst.

\begin{tabular}{|c|c|c|c|c|c|c|c|c|c|c|}
\hline \multirow[b]{2}{*}{ Entry } & \multirow[b]{2}{*}{ Pre-catalyst } & \multirow[b]{2}{*}{$\mathrm{Al}: \mathrm{M}$} & \multirow[b]{2}{*}{ Activity $^{a}$} & \multirow[b]{2}{*}{$\alpha-\mathrm{C}_{4}$} & \multicolumn{6}{|c|}{$\%$ Product distribution } \\
\hline & & & & & A & B & $\mathrm{C}$ & D & E & F \\
\hline 1 & 1 & 400 & 43.0 & - & 65.1 & 34.9 & - & - & - & - \\
\hline 2 & 2 & 400 & 54.0 & - & 64.2 & 35.8 & - & - & - & - \\
\hline 3 & 3 & 400 & 93.0 & - & 63.3 & 36.7 & - & - & - & - \\
\hline 4 & 4 & 400 & 100.0 & - & 62.0 & 38.0 & - & - & - & - \\
\hline 5 & 5 & 400 & 112.0 & - & 62.2 & 37.8 & - & - & - & - \\
\hline 6 & 6 & 350 & 190.0 & 43.3 & 1.8 & 25.5 & 4.5 & 13.0 & 1.5 & 10.3 \\
\hline 7 & 7 & 350 & 150.0 & 44.2 & 1.7 & 24.6 & 4.5 & 13.9 & 0.6 & 10.4 \\
\hline 8 & 8 & 350 & 173.0 & 43.2 & 1.8 & 24.9 & 4.6 & 13.0 & 2.1 & 10.4 \\
\hline 9 & 9 & 350 & 180.0 & 44.2 & 1.7 & 26.29 & 2.3 & 13.6 & 1.3 & 10.6 \\
\hline 10 & 10 & 350 & 216.0 & 44.3 & 1.2 & 25.87 & 2.5 & 14.6 & 0.6 & 10.5 \\
\hline
\end{tabular}

Conditions: amount of pre-catalyst Pd or $\mathrm{Ni}=10 \mu \mathrm{mol}, 10 \mathrm{~mL}$ toluene, $10 \mathrm{bar}, 1 \mathrm{~h}, 30^{\circ} \mathrm{C}$.

${ }^{a}$ Activity in $\mathrm{kg}$ product $\mathrm{mol}^{-1}$ metal $\mathrm{h}^{-1}$.

Experiments were run in triplicate.

Characterization of products by GC (Fig. 1) and GC-MS confirmed that the palladium catalysts gave only two products, mono-ethyltoluenes (A) and mono-butyltoluenes (B) (Scheme 2 ). So the palladium catalysts are selective in oligomerizing ethylene to butenes but with the low amount of butenes present in the reaction, the large amount of ethylene present appears to promote alkylation of toluene by to ethyltoluenes via a Friedel-Crafts alkylation process. However, with the nickel catalysts, the products were butenes and six alkyltoluenes, namely mono-butyltoluenes (B), di-butyltoluenes (D) and tri-butyltoluenes (F) as major products; and mono-ethyltoluenes (A), ethyl-butyltoluene $(\mathbf{C})$ and ethyldi-butyltoluenes $(\mathbf{E})$ as minor products (Scheme 2). For the palladium catalysts selectivity towards A ranged from 62 to $65 \%$, but the nickel catalysts are selective towards butene oligomers as primary product and butyltoluenes (B, D and $\mathbf{F}$ ) as secondary products (Table 1). The alkyltoluenes have regioisomers; formed as a result of toluene being activated at the ortho and para positions. For example compound $\mathbf{B}$ has three regioisomers; two can be attributed to butyl groups in ortho and para positions of the toluene and the third as branched, possibly from 2-butene from the isomerization of 1-butene before alkylation. The other alkylation products would have similar regioisomers if one considers alkylation in ortho and para positions and possible butene isomers.

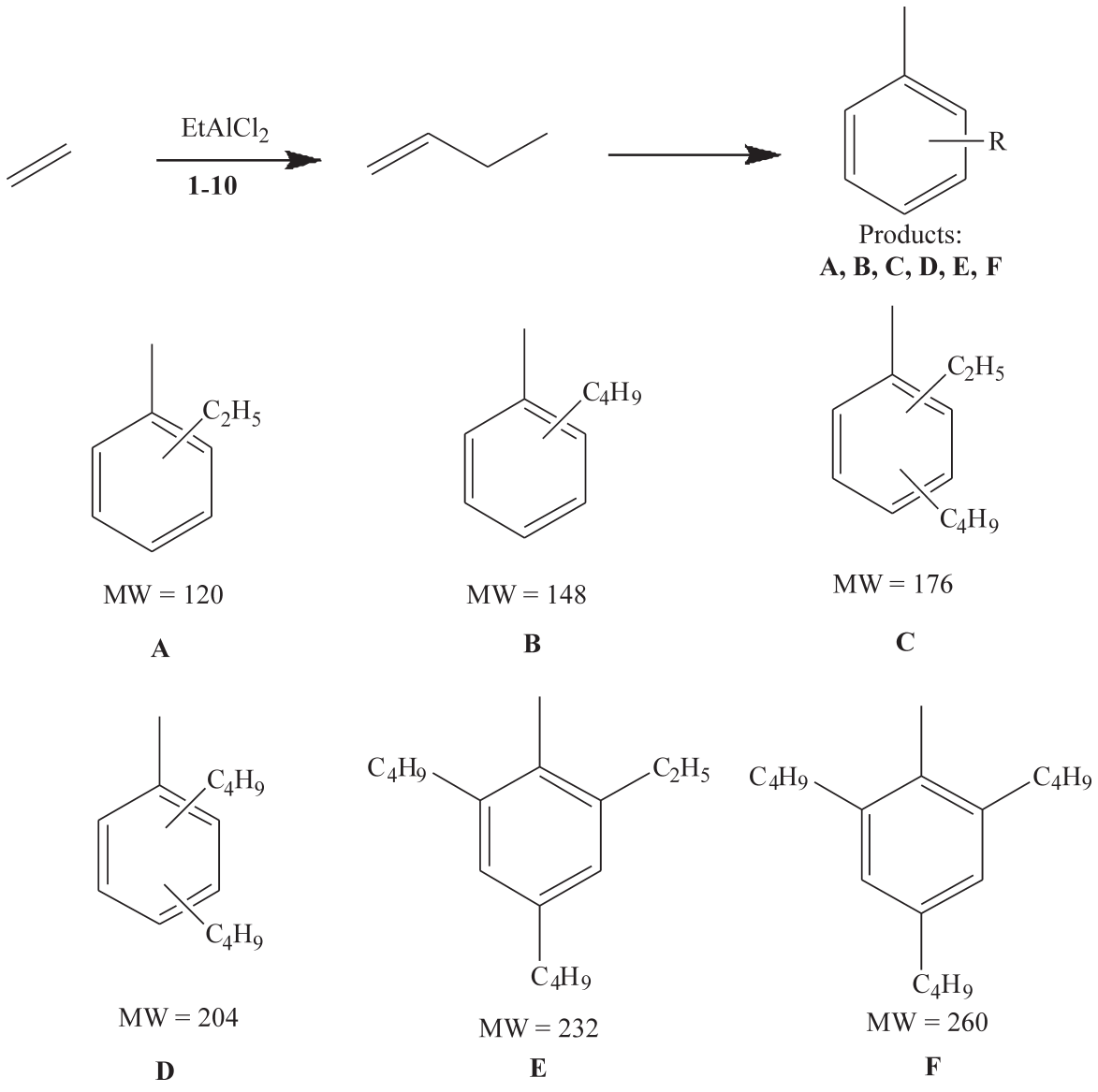

Scheme 2

Ethylene oligomerization and Friedel-Crafts reactions, showing typical alkyltoluene products. 


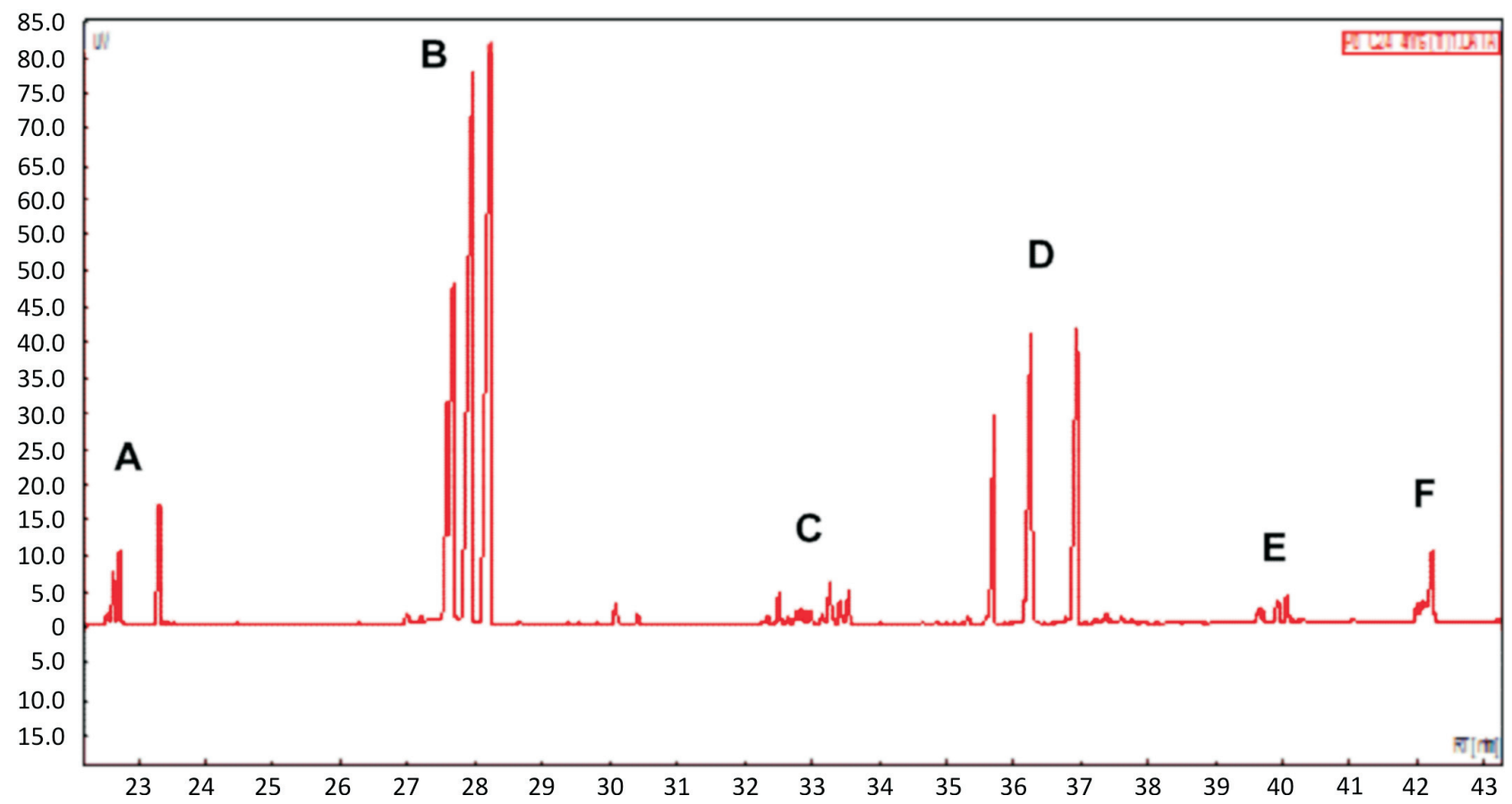

Figure 1 GC illustrating the alkylated toluene products and their respective regioisomers. Experiments were run in triplicate.

Having established that complexes $\mathbf{5}$ and $\mathbf{1 0}$ were the most active catalysts amongst the palladium and nickel compounds, respectively, we investigated effect of the concentration of EtAlCl ${ }_{2}$ on the ethylene reactions with 5 and $\mathbf{1 0}$. Table 2 is a summary of the data from this variation, indicating that for 5 and 10 the optimum co-catalyst:catalyst ratio was 370:1 and 550:1, respectively. These ratios were used in the subsequent variations of other parameters in the ethylene reactions with these two metal complexes.

\subsubsection{Effects of Temperature, Time and Pressure Variation on Catalysis}

A steady increase in catalyst activity was observed when temperature of the ethylene reactions was increased from $30^{\circ} \mathrm{C}$ to $50^{\circ} \mathrm{C}$ while time and pressure remained constant, but catalyst activity decreased above $50^{\circ} \mathrm{C}$ (entries 1-4,Table 3). For complex 5 at $30^{\circ} \mathrm{C}$ and $40^{\circ} \mathrm{C}$ only two products, $\mathbf{A}$ and $\mathbf{B}$, were observed. As the temperature increased to $50{ }^{\circ} \mathrm{C}$ and above, we observed the formation of $\mathbf{C}, \mathbf{D}, \mathbf{E}$ and $\mathbf{F}$ as additional products and a drastic reduction in the amount of $\mathbf{A}$ formed. When pressure and time were varied for this catalyst only changes in the proportions of products A-F were observed (entries 6-10, Table 3). Complex 10 produced mainly butenes, the alkyltoluene products B, D and F, and very small amounts of products that contain ethyl groups. For this catalyst optimum activity was $563.8 \mathrm{~kg} \mathrm{~mol}^{-1} \mathrm{Ni} \mathrm{h}^{-1}$ at $50^{\circ} \mathrm{C}$ compared to activity of $216.2 \mathrm{~kg} \mathrm{~mol}^{-1}$ $\mathrm{Pd} \mathrm{h}^{-1}$ for 5 at the same conditions. Increase in ethylene pressure increased activity for both $5\left(372.8 \mathrm{~kg} \mathrm{~mol}^{-1} \mathrm{Pd} \mathrm{h}^{-1}\right)$ and 10 (606.9 $\mathrm{kg} \mathrm{mol}^{-1} \mathrm{Ni} \mathrm{h}^{-1}$ ) (Table 3), with optimum activities at 20 bar. This is typical as increase in pressure of ethylene in the reactor would make more substrate available for the reaction. ${ }^{14}$ What is, however, unique is that for the palladium catalyst as temperature increased to $50{ }^{\circ} \mathrm{C}$ and above and also as time and pressure increased above $1 \mathrm{~h}$ and pressure above 10 bar, amounts of alkylation products also increased. This signifies that when the amount of butenes in the reactor is low, ethyltoluenes is the major product; but as the amount of butenes increased the main alkylation products are alkyltoulenes. Nickel catalysts are generally known for dimerizing ethylene, and since low amounts of butenes in these reactions resulted in more ethyltoluenes, it is not surprising the nickel catalyst produced mainly butyltoluenes. But compared to other pyrazolyl nickel catalysts reported in the literature ${ }^{11,12}$ that convert all ethylene oligomers from ethylene to alkyltoluenes, the current nickel catalysts are not able to convert all the butenes produced to butyltoluenes in spite of the large amount of $\mathrm{EtAlCl}_{2}$ used in these reactions. This suggests that the Friedel-Crafts alkylation is not catalyzed by the excess Et $\mathrm{AlCl}_{2}$ alone, otherwise all the ethylene reactions with the nickel complexes 6-10 would have produced exclusively butyltoluenes from butenes present in the product mix.

\subsubsection{Effect of Solvent on Ethylene Oligomerization and \\ Friedel-Crafts Alkylation Reactions}

Since the observed Friedel-Crafts alkylation of toluene occurred because toluene is an activated aromatic compound for FriedelCrafts reactions, we investigated the ethylene reactions with complex $\mathbf{1 0}$ in less activated aromatic solvents like benzene and chlorobenzene and in a non-aromatic solvent hexane. Of the two aromatic solvents, the more activated benzene produced butylbenzenes; but the less activated chlorobenzene produced butenes and high molecular weight ethylene oligomers (Table 4). The high molecular weight ethylene oligomers were isolated as viscous oily yellow liquids after evaporating the chlorobenzene. After initial attempt to characterize the oil by GC-MS failed, we run mass spectra of the oils using atmospheric pressure chemical ionization (APCI). The oils showed molecular weight in the region $501-580 \mathrm{~g} \mathrm{~mol}^{-1}$ representing a mixture of $\mathrm{C}_{18}$ to $\mathrm{C}_{20}$ olefins. In hexane, only ethylene oligomers $\left(\mathrm{C}_{12}\right.$ to $\mathrm{C}_{16}$ olefins) with molecular weight between $344-484 \mathrm{~g} \mathrm{~mol}^{-1}$ were identified by APCI. It is worth noting that in chlorobenzene and in hexane ethylene oligomers of similar high molecular weight were produced. Formation of these high molecular weight ethylene oligomers are unusual and could be due to further oligomerization of initially form $\mathrm{C}_{4}-\mathrm{C}_{8}$ that nickel and palladium catalysts are known to form when they oligomerize ethylene. It is also interesting to note reports on other nickel complexes and $\mathrm{EtAlCl}_{2}$ systems for ethylene reactions in toluene that do not yield any Friedel-Crafts alkyltoluenes products, ${ }^{9,10}$ which therefore confirms the role a ligand plays in this catalysis. Our 

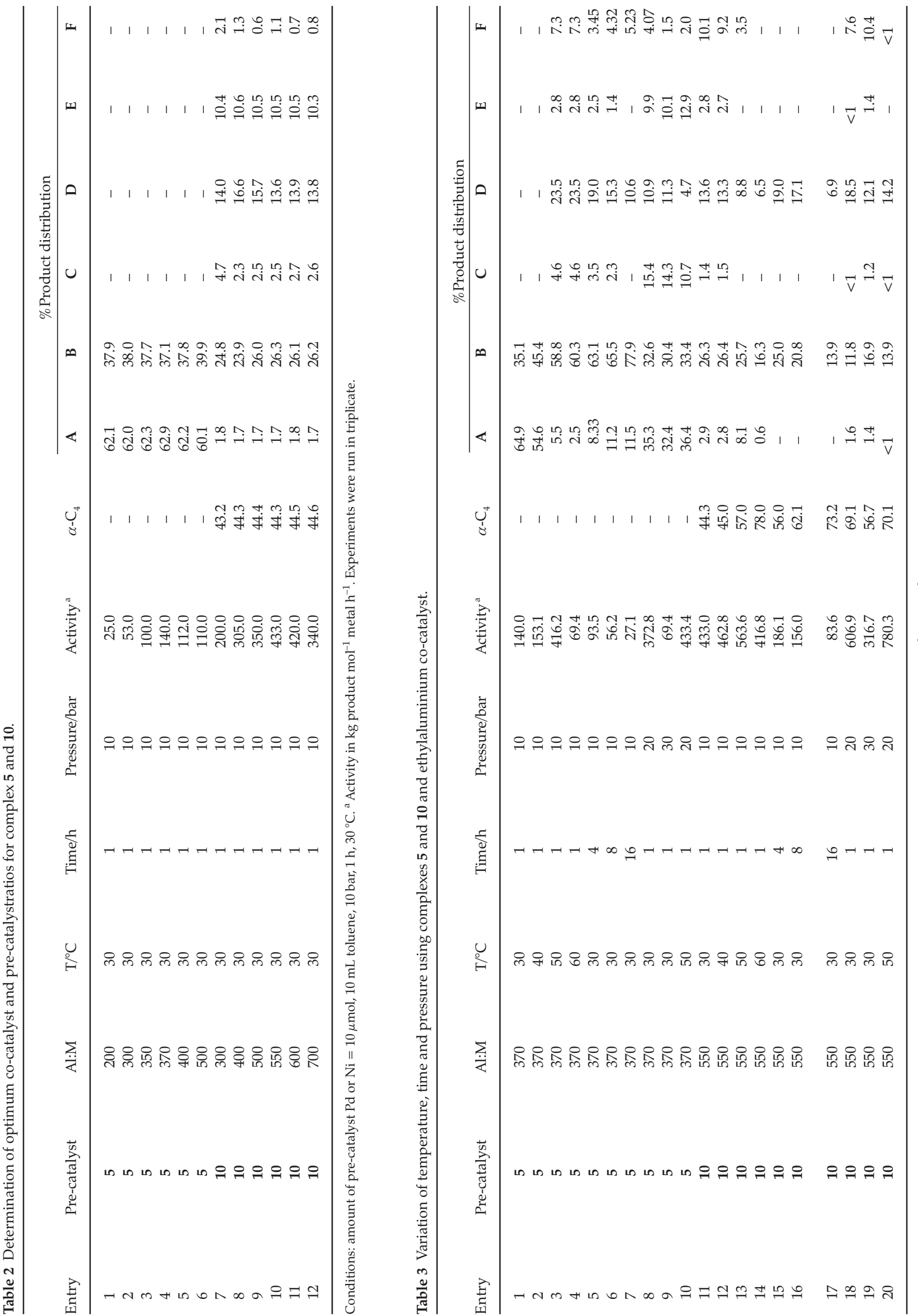
Table 4 Products formed upon solvent variation using ethylaluminium dichloride as co-catalyst and pre-catalyst 10.

\begin{tabular}{lcccccc}
\hline Solvent & Al:Ni & Activity & $\% \alpha-\mathrm{C}_{4}$ & \%Alkyl toluenes & \%Alkyl benzenes & Molar mass $/ \mathrm{g}$ mol $^{-1}$ \\
\hline Toluene & 550 & 563 & 44.3 & 55.7 & - & - \\
Chlorobenzene & 550 & 1272 & 68.0 & - & - & 508.98 \\
Benzene & 550 & 1044 & - & - & 100 & - \\
\hline
\end{tabular}

Conditions: amount of Ni pre-catalyst $=10 \mu \mathrm{mol}, \mathrm{Al}: \mathrm{Ni}=550: 1$, ethylene pressure $=10 \mathrm{bar}, 10 \mathrm{~mL}$ toluene, $50^{\circ} \mathrm{C}$. Experiments were run in triplicate.

catalysts therefore favour the formation of alkylaromatics.

We also investigated the effect of co-catalysts on the ethylene reactions using complex $\mathbf{1 0}$ (Table 5). With ethylaluminiumsesquichloride, $\mathrm{Et}_{3} \mathrm{Al}_{2} \mathrm{Cl}_{3}$, (EASC) there was considerable amount of butenes formed, up to twice as much as when the co-catalyst was EtAlCl . EASC also produced very small amounts of alkyltoluenes. The best EASC co-catalyst to nickel ratio was 600:1 and this was ratio used for further variations (Table 6). At low temperatures (e.g. at $20^{\circ} \mathrm{C}$ ) and low co-catalyst concentrations butene formation was $100 \%$, but at $50{ }^{\circ} \mathrm{C}$, only $4 \%$ of the product mix are alkyltoluenes. Activity with EASC was as high as 3130 $\mathrm{kg} \mathrm{mol}^{-1} \mathrm{Ni} \mathrm{h}^{-1}$, compared to $\mathrm{EtAlCl}_{2}\left(780 \mathrm{~kg} \mathrm{~mol} \mathrm{Ni} \mathrm{h}^{-1}\right)$. The high activity from the EASC reactions indicate the effectiveness of this ethylaluminium compound as a co-catalyst. ${ }^{16}$ Shorter reaction times also resulted in better selectivity towards the formation of butenes, while increased reaction times allowed for Friedel-Crafts alkylated products (entries 8-10). This proves that oligomerization initially occurs followed by alkylation of toluene with the oligomers formed or the monomer itself. Methylaluminoxane (MAO) and modified methylaluminoxane
(MMAO) as co-catalysts also produced butenes and but no alkyl toluenes, although catalysts activities were generally low (10 gave activities of $280 \mathrm{~kg} \mathrm{~mol}^{-1} \mathrm{Ni} \mathrm{h}^{-1}$ and $250 \mathrm{~kg} \mathrm{~mol}^{-1} \mathrm{Ni} \mathrm{h}^{-1} \mathrm{MAO}$ and MMAO, respectively). The production of alkyltoluenes appear to be driven by the acidity of the co-catalysts, so the least acid co-catalysts MAO and MMAO produced no alkyltoluenes at all whereas the most acidic co-catalyst $\mathrm{EtAlCl}_{2}$ produced the most alkyltoluenes.

\section{Conclusions}

Like other reported pyrazolyl nickel and palladium dihalides in the literature, bis(pyrazole)- and (bis-subsitutedpyrazoles)palladium and nickel can be activated with $\mathrm{EtAlCl}_{2}$ to produce catalysts for the dimerization of ethylene in toluene, benzene and chlorobenzene; but in toluene and benzene Friedel-Crafts alkylation of the solvents by ethylene and butenes occur and with selectivity towards mono-butyl and dibutyl-toluenes. Interestingly, the less active palladium catalysts resulted in significant amounts of mono-butyltoluenes compared to the nickel catalysts making the palladium complexes more selective

Table 5 The use of co-catalysts other than ethylaluminium dichloride and pre-catalyst $\mathbf{1 0}$.

\begin{tabular}{|c|c|c|c|c|c|c|c|}
\hline \multirow[t]{2}{*}{ Entry } & \multirow[t]{2}{*}{ Co-catalyst } & \multirow[t]{2}{*}{$\mathrm{Al} / \mathrm{Ni}$} & \multirow[t]{2}{*}{$\mathrm{T} /{ }^{\circ} \mathrm{C}$} & \multirow[t]{2}{*}{ Time/min } & \multirow[t]{2}{*}{ Activity $^{a}$} & \multicolumn{2}{|c|}{$\%$ Product distribution } \\
\hline & & & & & & $\alpha-\mathrm{C}_{4}$ & Butyltoluene \\
\hline 1 & MAO & 1500 & 30 & 30 & 280 & 100 & - \\
\hline 2 & MMAO & 1500 & 30 & 30 & 250 & 100 & - \\
\hline 3 & $\mathrm{Et}_{2} \mathrm{AlCl}$ & 500 & 30 & 30 & 820 & 100 & - \\
\hline 4 & $\mathrm{Et}_{3} \mathrm{Al}_{2} \mathrm{Cl}_{3}$ & 500 & 30 & 30 & 2290 & 99 & 1 \\
\hline
\end{tabular}

Conditions: amount of Ni pre-catalyst $=4 \mu \mathrm{mol}$, toluene: $100 \mathrm{~mL}$.

a Activity as: $\mathrm{kg} \mathrm{mol}^{-1} \mathrm{Ni} \mathrm{h}^{-1}$, pressure: 10 bar.

Experiments were run in triplicate.

Table 6 Variation of reaction parameters using EASC as co-catalyst for pre-catalyst 10.

\begin{tabular}{|c|c|c|c|c|c|c|c|}
\hline \multirow[t]{2}{*}{ Entry } & \multirow[t]{2}{*}{$\mathrm{Al}: \mathrm{Ni}$} & \multirow[t]{2}{*}{$\mathrm{T} /{ }^{\circ} \mathrm{C}$} & \multirow[t]{2}{*}{ Time/min } & \multirow[t]{2}{*}{ Activity $^{a}$} & \multirow[t]{2}{*}{ Pressure/bar } & \multicolumn{2}{|c|}{$\%$ Product distribution } \\
\hline & & & & & & $\alpha \mathrm{C}_{4}$ & $\mathrm{~F}-\mathrm{C}$ \\
\hline 1 & 400 & 30 & 30 & 1760 & 10 & $>99$ & $<1$ \\
\hline 2 & 500 & 30 & 30 & 2290 & 10 & 99 & 1 \\
\hline 3 & 600 & 30 & 30 & 2580 & 10 & 97 & 3 \\
\hline 4 & 700 & 30 & 30 & 2390 & 10 & 92 & 8 \\
\hline 5 & 600 & 20 & 30 & 900 & 10 & 100 & - \\
\hline 6 & 600 & 40 & 30 & 1990 & 10 & 98 & 2 \\
\hline 7 & 600 & 50 & 30 & 1790 & 10 & 96 & 4 \\
\hline 8 & 600 & 30 & 15 & 3130 & 10 & 100 & - \\
\hline 9 & 600 & 30 & 45 & 2430 & 10 & 96 & 4 \\
\hline 10 & 600 & 30 & 60 & 1280 & 10 & 90 & 10 \\
\hline 11 & 600 & 30 & 30 & 420 & 5 & 80 & 20 \\
\hline 12 & 600 & 30 & 30 & 48 & 1 & $>99$ & $<1$ \\
\hline $13^{*}$ & 600 & 30 & 30 & 490 & 10 & $>99$ & $<1$ \\
\hline
\end{tabular}

Conditions: amount of Ni pre-catalyst $=4 \mu \mathrm{mol}$, toluene: $100 \mathrm{~mL}$.

a Activity as: $\mathrm{kg} \mathrm{mol}^{-1} \mathrm{Ni} \mathrm{h}^{-1}$.

* Pd pre-catalyst $=4 \mu \mathrm{mol}$.

Experiments were run in triplicate. 
towards this product. Changing solvents also has a significant effect onthe ethylene reaction, with chlorobenzene and hexane producing viscous oils that is made up of $\mathrm{C}_{12}$ to $\mathrm{C}_{18}$ olefins. It is also clear that only $\mathrm{EtAlCl}_{2}$ as a co-catalyst produces catalysts that act in tandem to produce butenes and ethyl- and butyl-toluenes; as such the combination of these bis(pyrazolespalladium and nickel dihalides and $\mathrm{EtAlCl}_{2}$ can be seen in tandem for the production of these alkylaromatics.

\section{Experimental}

\subsection{Materials and Manipulations}

All syntheses of palladium and nickel complexes were carried in an inert atmosphere. Toluene was dried over sodium and benzophenone, distilled and stored under a nitrogen atmosphere. Chlorobenzene was dried over $3 \AA$ molecular sieves. Hexane was dried over sodium lumps, distilled and stored under $3 \AA$ molecular sieves. Ethylene $(99.9 \%$ ) was purchased from AFROX (South Africa) and used as received. The co-catalyst, ethylaluminium dichloride $\left(\mathrm{EtAlCl}_{2}\right), 25 \mathrm{wt} . \%(1.0 \mathrm{M})$ solution in hexanes was purchased from Sigma-Aldrich and used as received. The palladium starting material, $\left[\mathrm{PdCl}_{2}(\mathrm{NCMe})_{2}\right]$, was synthesized according to literature procedure. ${ }^{17}$ Compounds $\left[(\mathrm{pz})_{2} \mathrm{PdCl}_{2}\right](\mathbf{1}),\left[\left(3,5-\mathrm{Me}_{2} \mathrm{pz}\right)_{2} \mathrm{PdCl}_{2}\right](2),\left[\left(3,5-{ }^{t} \mathrm{Bu}_{2} \mathrm{pz}\right)_{2} \mathrm{PdCl}_{2}\right](3){ }^{6}$ and $\left[(\mathrm{pz})_{4} \mathrm{NiBr}_{2}\right](6),\left[\left(3,5-\mathrm{Me}_{2} \mathrm{pz}\right)_{2} \mathrm{NiBr}_{2}\right](7){ }^{7}$ were synthesized according to the literature procedures. Infrared (IR) spectra were recorded on a Bruker Tensor 27 equipped with a diamond ATR, elemental analyses were performed in house at the University of Johannesburg on a Flash 200 organic CHNS analyzer and at Rhodes University with a Varioelementar III microcube CHNS analyzer. The mass spectrometry unit at the University of Stellenbosch performed the HR-ESI-MS spectra on a Waters API Qualtro micro spectrophotometer. NMR spectra were recorded on a Bruker $400 \mathrm{MHz}$ instrument $\left({ }^{1} \mathrm{H}\right.$ at $400 \mathrm{MHz}$ and ${ }^{13} \mathrm{C}\left\{{ }^{1} \mathrm{H}\right\}$ at $100 \mathrm{MHz}$ ). The chemical shifts are reported in $\delta$ (ppm) and referenced to the residual proton and carbon signals $7.24 \mathrm{ppm}$ and $77.0 \mathrm{ppm}$ for $\mathrm{CDCl}_{3}$ and 2.49 and $39.5 \mathrm{ppm}$ for DMSO- $d_{6}$ for each respective NMR solvent. ${ }^{19} \mathrm{~F}\left\{{ }^{1} \mathrm{H}\right\}$ NMR spectra were also run with no internal standard in DMSO- $d_{6}$ or $\mathrm{CDCl}_{3}$ depending on solubility of the compound analyzed. GC and GC-MS were used to identify the products from the oligomerization and Friedel-Crafts reactions. GC-MS were recorded in-house at the University of Johannesburg on a Shimadzu GC-MS-QP2010 fitted with a quadrupole mass detector.

\section{Synthesis of (3,5-Ph $\mathrm{Pz}_{2} \mathrm{PdCl}_{2}(4)$}

3,5-Diphenyl-1H-pyrazole $(0.170 \mathrm{~g}, 0.772 \mathrm{mmol})$ was added to a suspension of $\left[\mathrm{PdCl}_{2}(\mathrm{NCMe})_{2}\right](0.10 \mathrm{~g}, 0.39 \mathrm{mmol})$ in toluene $(20 \mathrm{~mL})$. Yield: $0.20 \mathrm{~g}(85 \%) . \delta_{\mathrm{H}}\left(400 \mathrm{MHz}, \mathrm{DMSO}-d_{6}\right): 6.81(1 \mathrm{H}, \mathrm{s}$, $4-\mathrm{H} p z), 7.39\left(3 \mathrm{H}, \mathrm{t}, J 7.6 \mathrm{~Hz}, 3^{\prime}-\mathrm{H}, 4^{\prime}-\mathrm{H}\right.$ and $\left.5^{\prime}-\mathrm{H}\right), 7 . \overline{3} 9(3 \mathrm{H}, \mathrm{t}, J 7.6$ $\mathrm{Hz} 3^{\prime \prime}-\mathrm{H}, 4^{\prime \prime}-\mathrm{H}$ and $\left.5^{\prime \prime}-\mathrm{H}\right), 7.91\left(2 \mathrm{H}, \mathrm{d}, J 7.2 \mathrm{~Hz}, 2^{\prime}-\mathrm{H}, 6^{\prime}-\mathrm{H}\right), 8.11(2 \mathrm{H}$, d, J 7.6 Hz, 2"-H, 6"-H) and $13.75 \mathrm{ppm}(1 \mathrm{H}, \mathrm{s}, \mathrm{N}-\mathrm{H}) ; \delta_{\mathrm{C}}(100 \mathrm{MHz}$ DMSO- $\left.d_{6}\right)$ : 103.0 (C-4-pz), 125.9 (C-3', C-5'), 128.3 (C-3", C-5"), $129.4\left(\mathrm{C}-4^{\prime}, \mathrm{C}-4^{\prime \prime}\right), 128.2$ (C-2', C-6'), 129.5 (C-2", C-6"), 130.2 (C-1'), 133.3 (C-1"), 156.7 (C-3-pz) and 164.9 ppm (C-5-pz);HR-MS (ESI): $m / z(\%)=616.9883(70)[\mathrm{M}+\mathrm{H}]^{+}$. Found: $\mathrm{C}, 57.93 ; \mathrm{H}, 4.03$; $\mathrm{N}, 8.73 \%$. Calc. for $\mathrm{C}_{30} \mathrm{H}_{24} \mathrm{Cl}_{2} \mathrm{~N}_{4} \mathrm{Pd}: \mathrm{C}, 58.32 ; \mathrm{H}, 3.92 ; \mathrm{N}, 9.07 \%$.

\section{Synthesis of (3-CF 3 , 5 -Phpz $)_{2} \mathrm{PdCl}_{2}$ (5)}

A suspension of $\left[\mathrm{PdCl}_{2}(\mathrm{NCMe})_{2}\right](0.453 \mathrm{~g}, 1.175 \mathrm{mmol})$ in toluene $(20 \mathrm{~mL})$ was mixed with 5-phenyl-3-(trifluoromethyl)$1 \mathrm{H}$-pyrazole $(0.50 \mathrm{~g}, 2.35 \mathrm{mmol})$. Yield: $0.83 \mathrm{~g}(79 \%) . \delta_{\mathrm{H}}(400$ MHz, DMSO-d $\left.d_{6}\right) 6.34(1 \mathrm{H}, \mathrm{s}, 4-\mathrm{H} p z), 7.44\left(3 \mathrm{H}, \mathrm{t}, J 7.6 \mathrm{~Hz}, 3^{\prime}-\mathrm{H}\right.$, $4^{\prime}-\mathrm{H}$ and $\left.5^{\prime}-\mathrm{H}\right), 7.91\left(2 \mathrm{H}, \mathrm{d}, J 7.6 \mathrm{~Hz}, 2^{\prime}-\mathrm{H}, 6^{\prime}-\mathrm{H}\right), 13.75(1 \mathrm{H}, \mathrm{s}, \mathrm{N}-\mathrm{H}$ $p z) ; \delta_{\mathrm{C}}\left(100 \mathrm{MHz}, \mathrm{DMSO}-d_{6}\right): 101.5(\mathrm{C}-4 \mathrm{pz}), 123.5\left(\mathrm{q},{ }^{1} J_{\mathrm{F}, \mathrm{C}}=38.2\right.$ $\left.\mathrm{Hz}, \mathrm{C}-\mathrm{F}_{3}\right), 125.9$ (C-3', C-5'), 129.4 (C-4'), 129.6 (C-2', C-6' ); 128.5 $\left(\mathrm{C}-1^{\prime}\right), 144.6(\mathrm{C}-3 p z), 150.1(\mathrm{C}-5 p z) . \delta_{\mathrm{F}}\left(\mathrm{DMSO}-d_{6}\right):-60.41\left(\mathrm{CF}_{3}\right)$. IR (Diamond ATR, $\left.\mathrm{cm}^{-1}\right): v(\mathrm{~N}-\mathrm{H})=3226 \mathrm{~cm}^{-1} ; v\left(\mathrm{C}^{-}=\mathrm{N}\right)=1611 \mathrm{~cm}^{-1}$. HR-MS (ESI): $m / z(\%)=600.9453(100)[\mathrm{M}+\mathrm{H}]^{+}$. Found: C, 39.90, $\mathrm{H}, 2.35 ; \mathrm{N}, 9.31 \%$. Calc. for $\mathrm{C}_{20} \mathrm{H}_{14} \mathrm{Cl}_{2} \mathrm{~F}_{6} \mathrm{~N}_{4} \mathrm{Pd}: \mathrm{C}, 39.92 ; \mathrm{H}, 2.35 ; \mathrm{N}$, $9.31 \%$.

\section{Synthesis of $\left(3,5-{ }^{t} \mathrm{Bu} u_{2} p z\right)_{2} \mathrm{NiBr}_{2}(\mathbf{8})$}

3,5-Di-tert-butyl-1H-pyrazole $(0.50 \mathrm{~g}, 2.35 \mathrm{mmol})$ and [ $\left.\mathrm{NiBr}_{2}(\mathrm{DME})\right](0.54 \mathrm{~g}, 1.175 \mathrm{mmol})$ were dissolved in $\mathrm{CH}_{2} \mathrm{Cl}_{2}$ $(20 \mathrm{~mL})$ and gave a clear green solution. The mixture was allowed to react for $10 \mathrm{~min}$. After evaporation and purification a dark blue powder was obtained. Yield: $0.19 \mathrm{~g}(88 \%)$. HR-MS (ESI): $m / z(\%)=578.0965(56)[\mathrm{M}+\mathrm{H}]^{+}$. Found: $\mathrm{C}, 45.65 ; \mathrm{H}, 6.88$; $\mathrm{N}, 9.56 \%$. Calc. for $\mathrm{C}_{22} \mathrm{H}_{40} \mathrm{Br}_{2} \mathrm{~N}_{4} \mathrm{Ni}: \mathrm{C}, 45.63 ; \mathrm{H}, 6.96 ; \mathrm{N}, 9.68 \%$.

\section{Synthesis of $\left(3,5-\mathrm{Ph}_{2} \mathrm{pz}\right)_{2} \mathrm{NiBr}_{2}(9)$}

The preparation of 9 followed the same procedure as for 6 starting with 3,5-di-phenyl- $1 \mathrm{H}$-pyrazole $(2.5 \mathrm{~g}, 11.44 \mathrm{mmol})$ and $\left[\mathrm{NiBr}_{2}(\mathrm{DME})\right](1.25 \mathrm{~g}, 5.72 \mathrm{mmol})$ over a $24 \mathrm{~h}$ period yielding a green solid. Yield: $3.01 \mathrm{~g}(80 \%)$. HR-MS (ESI): $\mathrm{m} / z(\%)=658.0546$ (40) $[\mathrm{M}+\mathrm{H}]^{+}$. Found: $\mathrm{C}, 55.09 ; \mathrm{H}, 3.51 ; \mathrm{N}, 8.33 \%$. Calc. for $\mathrm{C}_{30} \mathrm{H}_{24} \mathrm{Br}_{2} \mathrm{~N}_{4} \mathrm{Ni}$ : C, 54.67; H, 3.67; N, $8.50 \%$.

\section{Synthesis of (3-CF, $5-\mathrm{Phpz})_{2} \mathrm{NiBr}_{2}(\mathbf{1 0})$}

5-Phenyl-3-(trifluoromethyl)-1H-pyrazole $(0.50 \mathrm{~g}, 2.35 \mathrm{mmol})$ and $\left[\mathrm{NiBr}_{2}(\mathrm{DME})\right](0.54 \mathrm{~g}, 1.175 \mathrm{mmol})$ were dissolved in $\mathrm{CH}_{2} \mathrm{Cl}_{2}$ $(20 \mathrm{~mL})$. Yield: $0.65 \mathrm{~g}(86 \%)$. IR (Diamond ATR, $\left.\mathrm{cm}^{-1}\right): v(\mathrm{NH})=$ $3228, v(\mathrm{C}=\mathrm{N})=1612$. HR-MS (ESI): $m / z(\%)=641.8819(100)$ $[\mathrm{M}]^{+}$. Found C, 37.36; $\mathrm{H}, 2.20 ; \mathrm{N}, 8.72 \%$. Calc. for $\mathrm{C}_{20} \mathrm{H}_{14} \mathrm{Br}_{2} \mathrm{~F}_{6} \mathrm{~N}_{4} \mathrm{Ni}$; C, 37.37; H, 2.20; N, $8.72 \%$.

\subsection{General Procedure for Ethylene Oligomerization and Friedel-Crafts Alkylation Reactions}

Oligomerization and Friedel-Crafts alkylation reactions were carried out in a $40 \mathrm{~mL}$ high-pressure reactor, which was dried at $100{ }^{\circ} \mathrm{C}$ and cooled under nitrogen to the desired temperature before use. An appropriate amount of pre-catalyst was added to the reactor under nitrogen together in degassed toluene $(10 \mathrm{~mL})$ and an appropriate amount of ethyl aluminium dichloride added with a syringe. Immediately after the addition of the EtAlCl${ }_{2}$, the reactor was charged with ethylene and the reactor temperature was maintained at the desired temperature. Ethylene pressure was set at the desired pressure maintained at this pressure during the reaction After the set reaction time, excess ethylene was vented and the reaction quenched by adding $2 \mathrm{M}$ $\mathrm{HCl}$ in methanol. The oily yellow product formed was filtered to remove any solid matter, washed with $2 \mathrm{M} \mathrm{HCl}$ in methanol and volatiles removed in vacuo. All experiments were run in triplicate.

\section{Acknowledgements}

We acknowledge financial support for this work from the University of Johannesburg and the DST-NRF Centre of Excellence in Catalysis ( ${ }^{*}$ change). We also thank Dr. Johan Jordaan at North West University for the APCI data.

\section{References}

1 (a) G. Natta, P. Pino, G. Mazzanti and U. Giannini, A crystallizable organometallic complex containing titanium and aluminium, J. Am. Chem. Soc., 1957, 79, 2975-2976. (b) A. Andersen, H.G. Cordes, J. Herwig, A. Merck, A.W. Kaminsky, R. Mottlier, J. Pein, H.K. Sinn and H.H. Vollmer, Halogen-free soluble Ziegler catalysts for ethylene polymerization. Regulation of molecular weight by selecting the 
reaction temperature, Angew. Chem., 1976, 88, 689-690. (c) H.K. Sinn and W. Kaminsky, Ziegler-Natta catalysis, Adv. Organomet. Chem., 1980, 18, 99-149. (d) P.J. Shapiro, W.P. Schaefer, J.A. Labinger and J.E. Bercaw, Model Ziegler-Natta $\alpha$-olefin polymerization catalysts derived from $\left[\left\{\left(\eta^{5}-\mathrm{C}_{5} \mathrm{Me}_{4}\right) \mathrm{SiMe}_{2}\left(\eta^{1}-\mathrm{NCMe}_{3}\right)\right\}\left(\mathrm{PMe}_{3}\right) \mathrm{Sc}\left(\mu_{2}-\mathrm{H}\right)\right]_{2}$ and $\left[\left\{\left(\eta^{5}-\mathrm{C}_{5} \mathrm{Me}_{4}\right) \mathrm{SiMe}_{2}\left(\eta^{1}-\mathrm{NCMe}_{3}\right)\right\} \mathrm{Sc}\left(\mu_{2}-\mathrm{CH}_{2} \mathrm{CH}_{2} \mathrm{CH}_{3}\right)\right]_{2}$. Synthesis, structures, kinetic and equilibrium investigations of the catalytically active species in solution, J. Am. Chem. Soc., 1994, 116, 4623-4640. (e) G.W. Coates, Precise control of polyolefin stereochemistry using single-site metal catalysts, Chem. Rev., 2000, 100, 1223-1252.

2 F.C. Mandelkern and L. Mandelkern, The glass temperature of linear polyethylene, Macromolecules, 1970, 3, 242-252.

3 B.L. Small and M. Brookhart, Iron-based catalysts with exceptionally high activities and selectivities for oligomerization of ethylene to linear $\alpha$-olefins, J. Am. Chem. Soc., 1998, 120, 7143-7144.

4 L.K. Johnson, M.C. Killian and M. Brookhart, New Pd(II)- and $\mathrm{Ni}(\mathrm{II})$-based catalysts for polymerization of ethylene and $\alpha$-olefins, J. Am. Chem. Soc., 1995, 117, 6414-6415.

5 G.J.P. Britovsek, V.C. Gibson, B.S. Kimberly, P.J. Maddox, S.J. McTavish, G.A. Solan, A.J.P. White and D.J. Williams, Novel olefin polymerization catalysts based on iron and cobalt, Chem. Commun., 1998, 849-850.

6 (a) K. Li, I. A Guzei, J. Darkwa and S.F. Mapolie, Synthesis and evaluation of substituted pyrazoles palladium(II) complexes as ethylene polymerization catalysts, J. Organomet. Chem., 2002, 660, 108-115. (b) H. Mkoyi, S.O. Ojwach and J. Darkwa, (Pyrazol-1-yl)carbonyl palladium complexes as catalysts for ethylene polymerization reaction, J. Organomet. Chem., 2013, 724, 95-101.

7 S.M. Nelana, J. Darkwa, I.A. Guzei and S.F. Mapolie, Ethylene polymerization catalyzed by substituted pyrazole nickel complexes. Synthesis and evaluation of substituted pyrazolespalladium(II) complexes as ethylene polymerization catalysts, J. Organomet. Chem. 2004, 689, 1835-1842. (b) C. Obuah, B. Omondi, K. Nozaki and J. Darkwa, Solvent and co-catalyst dependent pyrazolylpyridinamine and pyrazolylpyrroleaminenickel(II) catalyzed oligomerization and polymerization of ethylene, J. Mol. Catal. A: Chem., 2014, $382,31-40$.

8 (a) J.T. Dixon, M.J. Green, F.M. Hess, and D.H. Morgan, Advances in selective ethylene trimerisation - A critical overview, J. Organomet. Chem., 2004, 689, 3641-3668. (b) Z. Weng, S. Teo, L.P. Koh, and T.S.A. Hor, A structurally characterized Ni-Al methyl-bridged complex with catalyticethylene oligomerization activity, Chem. Coтmun. 2006, 110, 1319-1321. (c) C.M. Killian, L.K. Johnson, and M. Brookhart, Preparation of linear $\alpha$-olefins using cationic nickel(II) $\alpha$-diimine catalysts, Organometallics, 1997, 16, 2005-2007. (d) P. Hao, S. Zhang, W-H. Sun, Q. Shi, S. Adewuyi, X. Lu and P. Li, Synthesis, characterization and ethylene oligomerization studies of nickel complexes bearing 2-benzimidazolylpyridine derivatives, Organometallics, 2007, 26, 2439-2446. (e) N. Ajella, M.C. Kuhn, A.D.G. Boff, M. Horner, C.M. Thomas, J-F. Carpentier and O.L. Casagrande Jr., Nickel complexes based on tridentate pyrazolyl ligands for highly efficient dimerization of ethylene to 1-butene, Organometallics, 2006, 25,1213-1216. (f) R. Gao, M. Zhang, T. Liang, F. Wang and W-H. Sun,
Nickel(II) complexes chelated by 2-arylimino-6-benzoxazolylpyridine: syntheses, characterization, and ethylene oligomerization, Organometallics, 2007, 27, 5641-5648. (g) W-H. Sun, K. Wang, K. Wedeking, D. Zhang, S. Zhang, J. Cai and Y. Li, Synthesis, characterization, and ethylene oligomerization of nickel complexes bearing $\mathrm{N}$-((pyridin-2-yl)methylene)quinolin-8-amine derivatives, Organometallics, 2007, 26, 4781-4790. (h) W-H Sun, Z. Li, H. Hu, B. Wu, H. Yang, N. Zhu, X. Leng and H. Wang, Synthesis and characterization of novel nickel(II) complexes bearing N,P ligands and their catalytic activity in ethylene oligomerization, New. J. Chem., 2002, 26, 1474-1478. (i) M.K. Ainooson, S.O. Ojwach, I.A. Guzei, L.C. Spencer and J. Darkwa, Pyrazolyl iron, cobalt, nickel and palladium complexes: synthesis, molecular, structure, and evaluation as ethylene oligomerization catalysts, J. Organomet. Chem., 2011, 696, 1528-1535. (j) C. Obuah, B. Omondi, K. Nozaki and J. Darkwa, Solvent and co-catalyst dependent pyrazolylpyridinamine and pyrazolylpyrroleaminenickel(II) oligomerization and polymerization of ethylene, J. Mol. Catal. A: Chem., 2014, 382, 31-40. (k) G.A. Nyamato, S.O. Ojwach and M.P. Akerman, Unsymmetrical (pyrazolymethyl) pyridine metal complexes as catalysts for ethylene oligomerization reactions: role of solvent and co-catalyst in production distribution, J. Mol. Catal. A: Chem., 2014, 394, 274-282.

9 P.W. Dyer, J. Fawcett and M.J. Hanton, Rigid N-phosphino guanidine $\mathrm{P}, \mathrm{N}$ ligands and their use in nickel-catalyzed ethylene oligomerization, Organometallics, 2008, 27, 5082-5087.

10 K. Song, H. Gao, F. Liu, J. Pan, L. Luo, S. Zai and Q. Wu, Syntheses, structures, and catalytic ethylene oligomerization behaviors of bis(phosphanyl)aminenickel(II) complexes containing N-functionalized pendant groups, Eur. J. Inorg. Chem., 2009, 3016-3024.

11 S.O. Ojwach, I.A. Guzei, L.L. Benade, S.F. Mapolie and J. Darkwa, (Pyrazol-1-ylmethyl)pyridine nickel complexes: ethylene oligomerization and unusual Friedel-Crafts alkylation catalysts, Organometallics, 2009, 28, 2127-2133.

12 A. Budhai, B. Omondi, S.O. Ojwach, C. Obuah, E.Y. Osei-Twum and J. Darkwa, Tandem ethylene oligomerisation and FriedelCrafts alkylation of toluenecatalyzed by bis-(3,5-dimethylpyrazol1 -ylmethyl)benzene nickel(II) complexes and ethylaluminium dichloride, Catal. Sci. Technol., 2013, 3, 3130-3139.

13 W. Keim, E. Hoffman, R. Lodewick, M. Pauckert, G. Schmitt, J. Fleischhauer and U. Meier, Linear oligomerization of olefins via nickel chelate complexes and mechanistic considerations based on semi-empirical calculations, J. Mol. Catal., 1979, 6, 79-97.

14 M.D. Doherty, S. Trudeau, P.S. White, J.P. Morken and M. Brookhart, Ethylene oligomerization catalyzed by a unique phosphine-oxazolinepalladium(II) complex. propagation and chain transfer mechanisms, Organometallics, 2007, 26, 1261-1269.

15 B. Bogdanovic, Selectivity control in nickel-catalyzed olefin oligomerization, Adv. Organomet. Chem., 1979, 17, 105-140.

16 M. Vatankhah-Varnoosfaderani, S. Pourmahdian and F. AfsharTaromi, High performance bulky $\alpha$-diiminenickel(II) catalysts for ethylene polymerization, Iran. Polym. J., 2011, 20, 897-912.

17 D. Drew and J.R. Doyle, Cyclic diolefin complexes of platinum and palladium, Inorg. Synth., 1972, 13, 47-55. 
SUPPLEMENTARY MATERIALS - L.P. Moeti and J. Darkwa, S. Afr. J. Chem., 2016, 69, 236-243.

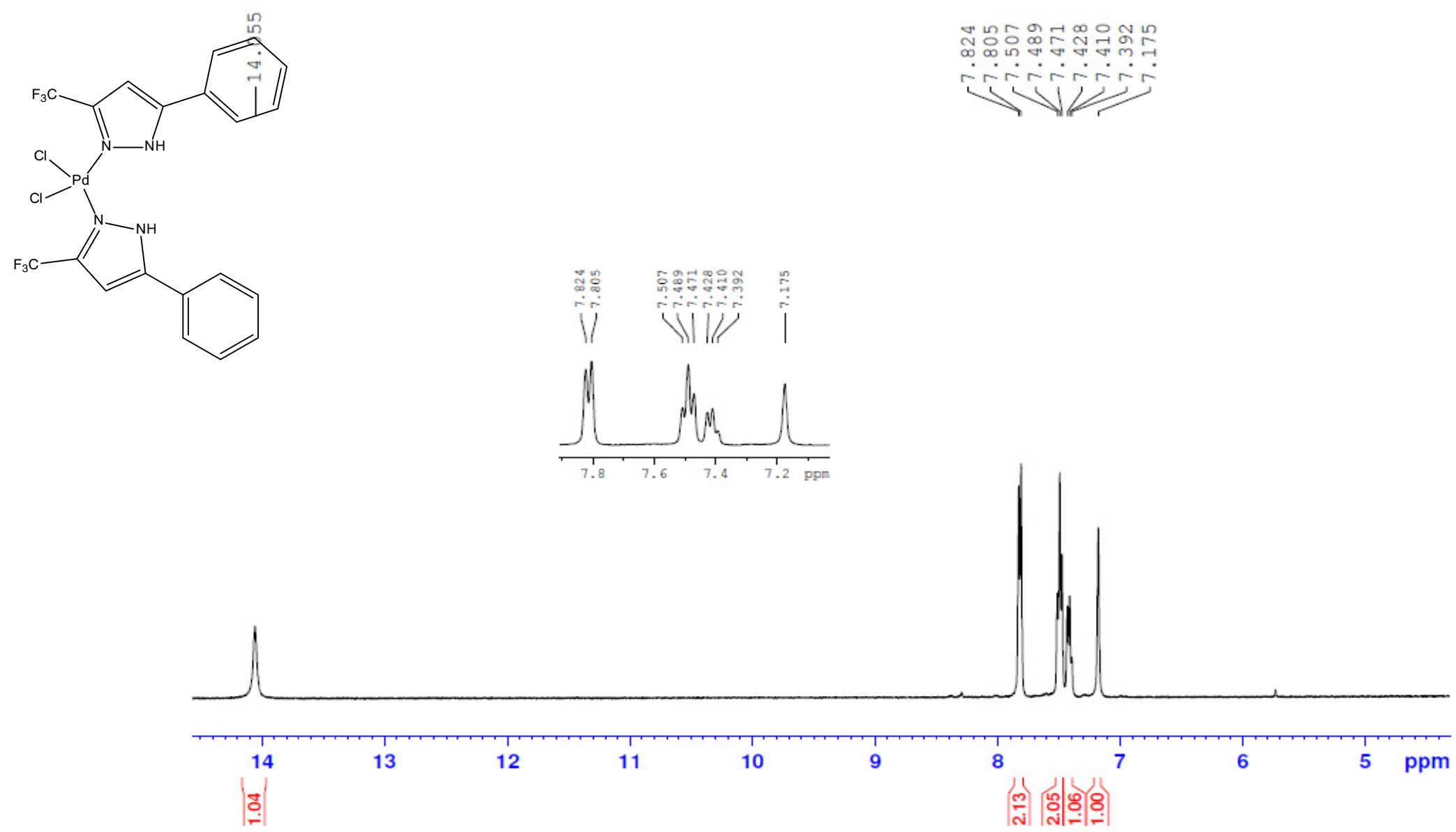

Figure S1: ${ }^{1} \mathrm{H}$ NMR spectrum for complex5. 


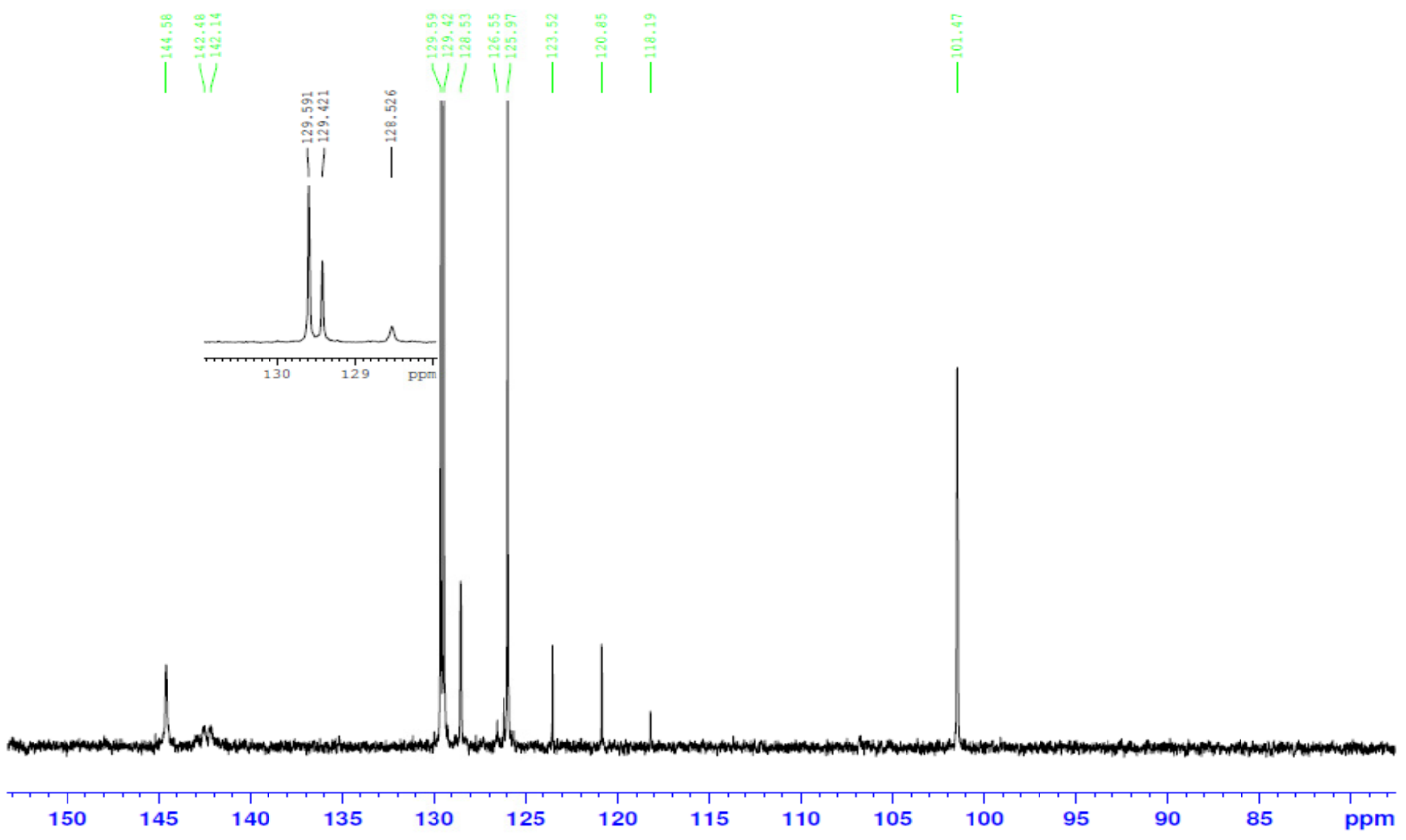

FigureS2: ${ }^{13} \mathrm{C}\left\{{ }^{1} \mathrm{H}\right\}$ NMRspectrum of complex 5 . 

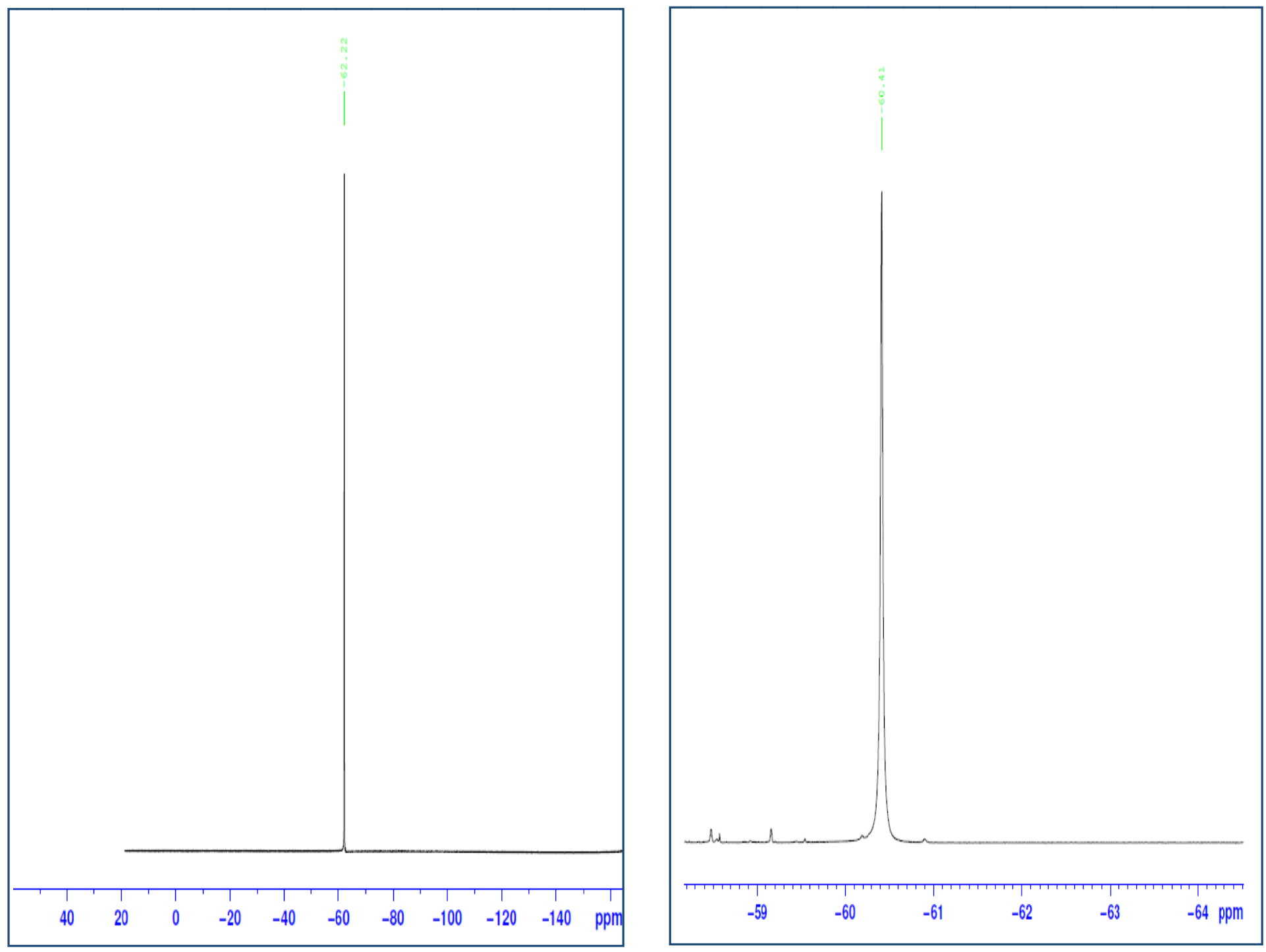

Figure S3: ${ }^{19} \mathrm{~F}\left\{{ }^{1} \mathrm{H}\right\}$ NMR spectra of $\mathbf{L 5}$ at -62.22 ppm with that of complex $\mathbf{5}$ at -60.44 ppm. 


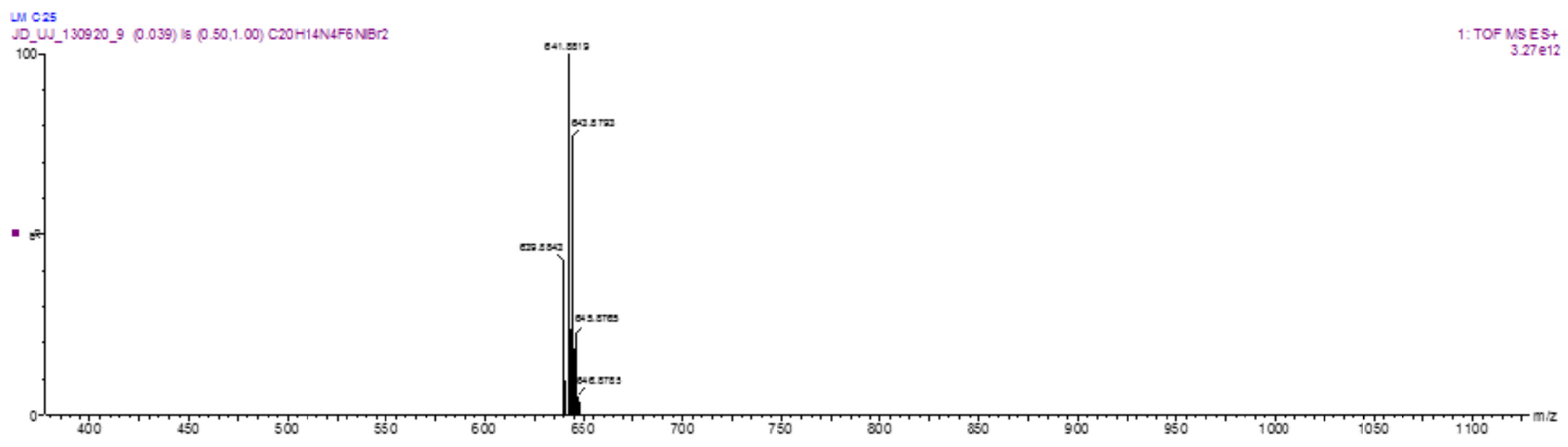

\section{LM C25}

JD_UJ_130920_9 (0.039) is $(0.50 .1 .00) \mathrm{C} 20 \mathrm{H} 14 \mathrm{~N} 4 \mathrm{~F} 6 \mathrm{NiBr} 2$

$\left.{ }^{100}\right]$

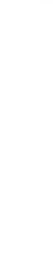

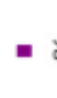

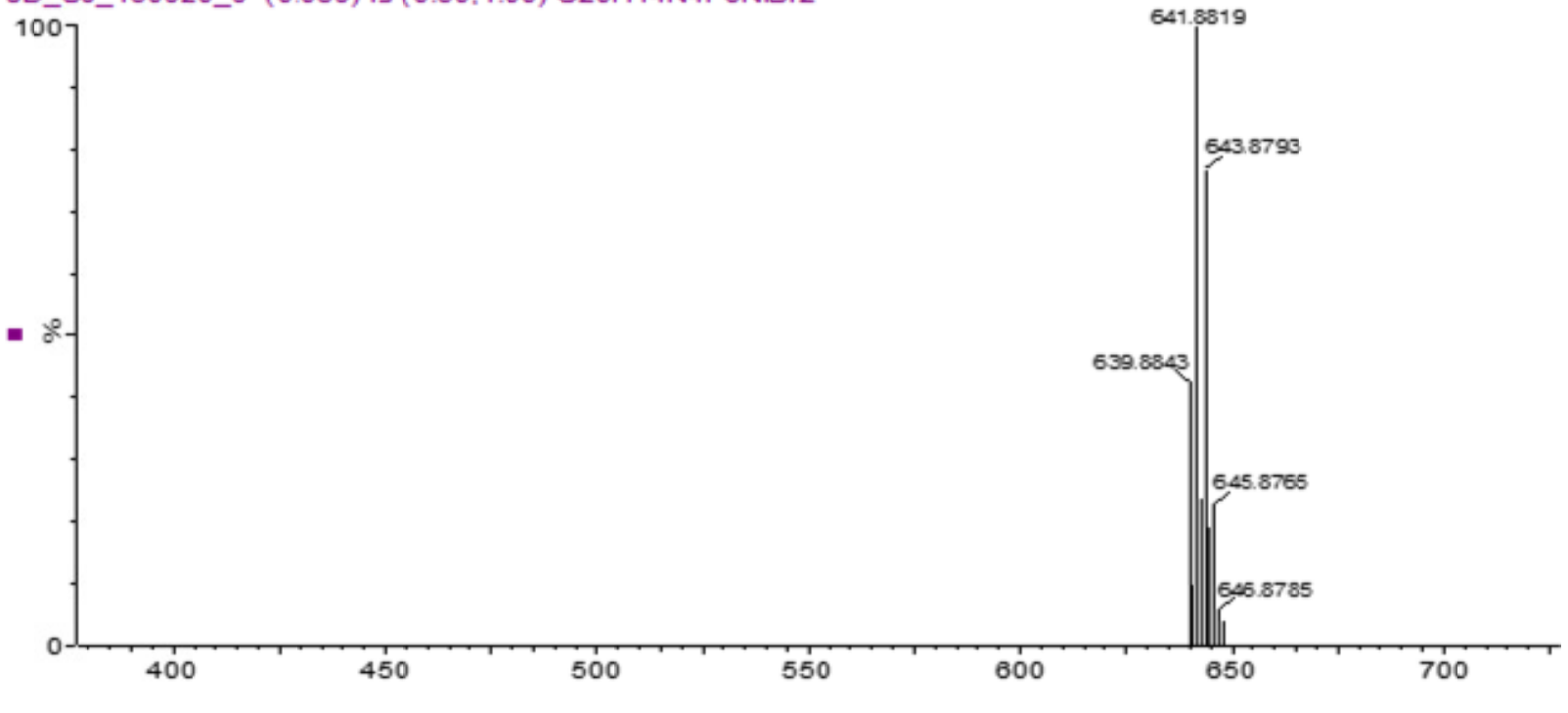

FigureS4: High resolution Mass Spectrum of complex 10.

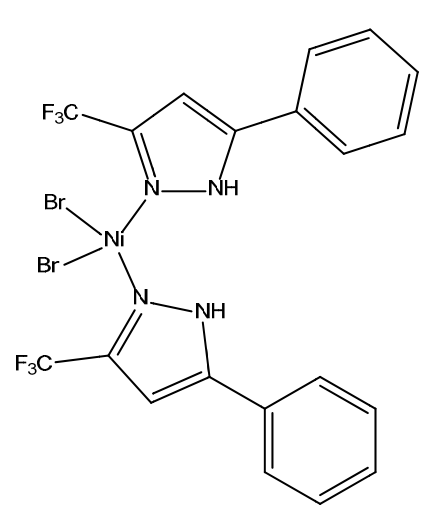

